\title{
The Preference of The Sub-Urban Society in Choosing The Satellite Area of Denpasar City as a Residential
}

\author{
Agung Angga Wira Raditya ${ }^{1}$, Ngakan Putu Sueca ${ }^{2}$, Ida Bagus Gde Wirawibawa ${ }^{3}$
}

\author{
Master Programs of Architecture \\ Faculty of Engineering-Udayana University \\ Jimbaran \\ anggawr93@gmail.com \\ Department of Architecture \\ Faculty of Engineering-Udayana University \\ Jimbaran \\ Department of Architecture \\ Faculty of Engineering-Udayana University \\ Jimbaran
}

\begin{abstract}
Villages suburb area around the border with the city of Denpasar is one of the area that's also effected by the economic growth in Denpasar city. The area was settled by people due to sub-urban residential land in Denpasar increasingly difficult to reach and limited, especially those located in the center of Denpasar City. It makes people prefer living in the satellite city of Denpasar. The area included in the district of Gianyar, Badung, and Tabanan regency. This study aims to determine the preference that are considered sub-urban communities to choose satellite settlements in Denpasar. This study uses the positivist approach with merging between qualitative and quantitative case study. The research result obtained five factors are considered sub-urban communities to choose satellite settlements in Denpasar, among others: accessibility, availability of shopping facilities, environmental conditions, availability of electricity, and the pierce of land/house. Thus, accessibility becomes a major factors in the selection of the sub-urban residential location in the satellite city of Denpasar.
\end{abstract}

Index Terms — preference, settlement, sub-urban, sattellite settlement

\section{INTRODUCTION}

The massive urbanization of the Asian region has brought opportunities as well as problems for cities in Asia. One thing that is often highlighted by city observers is the chaotic problem of urban spatial planning in Asia as a result of the unpreparedness of cities in anticipating a population explosion (Ellisa, 2009). The population explosion in Indonesia shows interesting conditions. The number of urban residents in Indonesia has exceeded the number of rural residents in 2008 and is expected to continue to increase until it reaches around 68 percent by 2025 (Siregar, 2012). The increase in population in Indonesia is an indication of the phenomenon of increasing urbanization in the country. In dealing with the phenomenon of urbanization, there are generally two different views. First, the view that understands urbanization as a negative phenomenon and the root cause of all urban problems, so that urbanization must be continuously suppressed. Second, the view that sees urbanization as a global phenomenon and an inevitable natural phenomenon, but on the other hand requires the handling and support of city management capacities that are able to keep pace with the rate of urbanization.

The solution for managing urbanization and increasing 
the capacity of basic city services is the creation of sustainable cities. Based on the Research Triangle Institute (1996), in creating a sustainable city, five basic principles are needed which are basically the development of three main dimensions (economic, social, and environmental). The development of new cities and large-scale settlements in Indonesia currently shows a less direct and controlled development trend. This condition, if left unchecked, will disrupt the balance of the city system and regional constellations (Agustina, 2007).

The development of a city that is less directed and controlled often occurs in metropolitan cities. Metropolitan is indicated by Angotti (1993) which began to develop in various major regions of the world in the 20th century and is a different form of a city, because it has a larger and more complex size in terms of economy, politics and culture. In addition, metropolitan areas generally have a large role globally, for example, metropolitan areas in Indonesia have special roles and functions based on Government Regulation no. 47 of 1987 as a National Activity Center (PKN) for the core city and Regional Activity Center (PKW) which serves as a gateway to the international area and a center for activities and transportation for several provinces (Vioya, 2010). Metropolitan city is synonymous with sub-urban activities. The phenomenon of suburbanization is defined as the process of forming new settlements and industrial areas on the outskirts of urban areas, especially as a result of the displacement of urban residents who need a place to live and for industrial activities (Kusumaningrum, 2014).

This sub-urban phenomenon encourages the presence of satellite cities around the metropolitan city. A satellite city or what can also be called a hinterland area can be defined as a small town located around a large city, which has the same performance pattern but in a smaller scope. In the hinterland area there are still economic activities, education, health or other facilities but on a small scale, not complex in big cities or city centers (Febriyani, 2014).

The presence of these satellite areas requires the application of a good spatial system so that in the future it does not cause disturbances in the balance of the city system and regional constellations. Booth (1995) in Sanger (2010) states that there are two spatial systems, namely regulatory and discretionary. The basis of the regulatory system is the existence of detailed zoning regulatory documents to regulate land use and other technical requirements that must be met to carry out development. This zoning regulation is legally validated as a binding regulatory document, so that violation of this zoning regulation becomes an illegal act. The only forum for questioning is through court proceedings. The discretionary system for making development implementation decisions is based on individual consideration of each development proposal submitted to the competent authority to make decisions. In this system, thinking and determining what can or should not be built or developed in an area is carried out after a proposal is submitted for development. The decision to implement development is granted through the granting of planning permission from the local planning agency. To obtain this planning permit, each development proposal must go through a set of predetermined standard procedures. The application of the spatial system in Indonesia tends to use a discretionary system. This system has significant drawbacks. This is because the authority of the local planning agency is so great that decisions taken can be political in nature so that they only benefit a group of people without paying attention to the interests of other communities.

Denpasar can be categorized as a metropolitan city when referring to the definition presented by Angotti (1993) in Vioya (2010). The sub-urban phenomenon also occurs in Denpasar. This is shown by the movement of workers from Denpasar to satellite areas such as in Badung, Gianyar and Tabanan. The sub-urban phenomenon in Denpasar is not as big as the sub-urban phenomenon that occurs in Jakarta, where more than $50 \%$ of its workforce lives in the BogorTangerang-Bekasi satellite area. However, that does not mean that this condition is not interesting to study. It is precisely when this sub-urban phenomenon has just arrived, it is very good to conduct an assessment so that this phenomenon does not cause problems related to spatial planning, population and various other social problems.

The initial assessment of the sub-urban phenomenon in Denpasar was carried out by knowing the factors considered by the sub-urban community to live in a satellite area. These factors are actually the forms of desire of the sub-urban community for the satellite area. If the various forms of desire are identified, the government as the holder of the regulation will easily exercise control. The private sector as a developer will also benefit, because the identification of this desire will be easier to meet the expectations of potential customers.

\section{RESEARCH METHODS}

This study analyzes the attitudes and behavior of sub-urban communities in a particular sample. Data collection uses a research instrument in the form of a questionnaire. The research method used combines the research methods conducted by Siswanta (2013) and Kalesar (2013). The results of the analysis will be narrated based on the results of statistical testing. There are two types of data sources, namely primary data and secondary data.

The primary data used includes the respondents' responses to the questions asked related to the indicators of each research variable. Secondary data is data that is processed by other people or institutions and has been published. These data can be obtained from the results of previous research and housing developers in the form of house specifications and housing facilities that support this research. 
After getting the data, there is validity and reliability testing. According to Umar (2004: 127) validity in research is explained as a degree of accuracy of research measuring instruments about the core or actual meaning being measured. The level of validity indicates the extent to which the collected data does not deviate from the description of the variable in question. According to Umar (2004: 126) reliability is the degree of accuracy, precision or accuracy shown by the measurement instrument where the test can be done internally, namely testing by analyzing the consistency of existing items.

\section{TEORY AND LITERATURE}

\section{A. Satelite Area}

The satellite area referred to in this case is a small town on the edge of a large city which, although it is an independent community, most of its residents depend on life in the big city. Usually the inhabitants of this satellite city are commuters from big cities. Satellite area is a supporting area for big cities in the vicinity and is a 'bridge' of entry / access to big cities. Because the satellite area also functions as a support for large cities, the implications of the satellite area as a support will be seen in the daily lives of its citizens (Wikipedia). In addition, according to F. Schnore, a satellite city is an area that has urban characteristics and this area provides the carrying capacity for city life. Satellite cities are formed as a result of developments that occur in the inner city. Satellite cities are small centers in the industrial sector that function as production cities.

\section{B. Settlement}

Settlements are part of the environment outside protected areas, which can constitute urban and rural areas. It functions as a place of residence / occupancy and a place for activities that support the life and livelihoods. Settlement can also be interpreted as housing or a collection of houses with all the elements and activities that are related and that are in the settlement.

Settlements are often referred to as housing. Settlement comes from the word housing in English which means housing and the word human settlement which means settlement. Housing gives the impression of a house or a collection of houses along with environmental infrastructure and facilities. Housing focuses on physical or inanimate objects, namely houses and land settlements. Settlements give the impression of settlers or groups of settlers along with their attitudes and behaviors in the environment, so that settlements focus on something that is not physical or inanimate objects, namely humans (Kurniasih, 2007; 3).

\section{Sub-Urban}

Sub-Urban is a combination of the words sub and urban, is a residential area located in the suburbs, not far from the city center. The emergence of this area is partly due to the expansion of the city, namely by the addition of a network of new roads, causing land expansion. The definition of a sub-urban community is a community who has a house and lives on the outskirts of a city (not a big city) but they earn a living in a big city. The definition of a suburban area is an area where commuters live. The characteristics of the area or the characteristics of this suburban area are a mixture of villages and cities. Some areas will show the shape of the city, but on the other hand show the characteristics of the countryside. This is because initially this area was also a rural area that was undergoing a transition process into an urban area.

Sub-urban communities are increasingly growing in line with increasingly limited and expensive land prices in the city center. They then build houses or industries which then live in the suburban area. The process which is then called suburbanization is a natural process of change in an effort to improve the welfare of the population or society.

Although the results are not significant, this has a positive impact on the main city, namely it can help control the population. Meanwhile, the suburban area itself is very supportive to accelerate regional development. Suburban communities that have contributive abilities can be a buffer for the life of the main city, but on the other hand, suburban communities will only become a burden if they do not have this contributive ability. What is very striking about the life of the suburban community is the almost empty residential area during the day, because most of the people work in the city. However, there are also some residents who work in agriculture.

\section{Teory of Sub-Urban}

First, the Urban Life Cycle theory by Van Den Berg. This theory states that there are four stages of urbanization, namely urbanization, suburbanization, deurbanization and reurbanization (Burian and Voženílek, 2012). Van Den Berg builds his theoretical framework from the micro level through the analysis of the behavioral functions of urban individuals. Van den Berg assumes that urban actors aim to maximize their welfare (not utility or wealth). The attractiveness 
of a residential or business location depends on the size and quality of the elements of well-being offered. These factors point to the fact that people do not always depend on elements of local welfare alone. The availability of welfare elements in a suitable location as a whole and relevant influences their spatial behavior. For residents, the element of welfare includes factors related to the immediate home and environment, access to jobs and access to facilities. For companies, these factors include potential location, labor market potential, input potential and market-potential. In short, changes in the behavior of urban actors lead to urban changes. In Van den Berg's model, changes in the spatial behavior of urban actors are caused by fundamental developments (economic, social, political, technological, demographic), which affect the mobility, preferences and aspirations of the actors (Braun, 2008).

Second, the theory of land demand put forward by Robert Margo is based on the post-war suburbanization process in the United States (Glaisser and Kahn, 2003). Margo argues that increased income over the past 50 years has increased the demand for land and that the increase in suburbanization between 1950 and 1980 can be explained by an increasingly richer people. The methodology he uses is to look at the relationship between income and suburban life in the 1950s and shows that if the relationship remains constant, an increase in income will push large numbers of people to suburban areas (Glaisser and Kahn, 2003). This shows that increasing income is an important factor in promoting the suburbanization of the population.

Third, the theory of Natural Evolution (natural evolution theory) which is favored by urban experts and transportation experts (Mieszkowski and Mills, 1993). When employment is concentrated in the city center, around stations or ports, residential development moves from within and then outwards. To minimize the cost of traveling to the center of business activity, housing development in urban centers is developed first then moves to suburban areas by opening new lands. As new housing in the suburbs, those with high incomes could afford to buy a bigger, more modern house and then settle down there. The majority of the middle class prefer to live in suburban areas rather than living in dense settlements in the city center. The tendency of the middle class to live in suburban areas is reinforced by innovations in transportation and considerations of travel time. As roads, railroads, and motorized vehicles were developed, this made travel faster. An increase in people's real income increases the ability to use faster modes of transportation. Access to suburban or suburban areas is made easier. This encourages the development of settlements in suburban areas which are then followed by the decentralization of employment where companies follow the movement of the population to the periphery by establishing factories and so on. Companies can take advantage of lower wages in suburban areas and cheaper land rents. The theory of natural evolution emphasizes the distance from the place of residence to the center of work, the effect of real income that increases over time, the demand for housing and new land, and a diverse housing supply. Other important considerations in this theory are the cost of transportation, transportation innovation in cities and the change in time as a comparison of the advantages of different income groups in traveling long distances for work.

Fourth, the theory of flight from blight. This theory emphasizes fiscal and social problems in main cities, such as high taxes, low quality public schools and other government services, racial tensions, crime, congestion and low environmental quality. These problems caused the wellto-do residents in the main cities to migrate to the suburbs. Those who move to the suburbs seek to form homogeneous communities, for several reasons. There is a preference for being among individuals with a certain income, education, race and ethnicity. The formation of a homogeneous society is also motivated by various demands for local goods, caused by differences in income and tastes (Mieszkowski and Mills, 1993). The model built on this theory focuses on the migration of ethnic minorities and low-income groups to the main cities, and the cumulative decline in the main city as a driving force of suburbanization (Byun and Esparza, 2005). The increasing numbers of low-income and ethnic minorities in the main cities after World War II deepened the tax burden of the middle class, increased social problems and was exacerbated by ethnic tensions (Mieszkowski and Mills 1993). As a result, there has been a relocation of the middle and business class to suburban areas. Due to this trend of suburbanization, tax revenues from the city center are reduced. A decrease in total tax revenue results in a decline in the quality of public services and infrastructure, and increases the tax burden on urban center residents. In particular, services in the main city have decreased and the environment has been deteriorating for the middle class, especially those who own homes. Home owners tend to be sensitive to negative changes in the environment that can threaten the value of their homes. As a result of being surrounded by the decline that occurred in the city center, the middle class was attracted (flight from blight) to the suburban community (suburban). Once there, they form their own community based on social homogeneity and relatively free of heavy tax burdens.

Fifth, the theory of market failure. This theory explains market failures that encourage the spread of population to suburban areas. Market failure includes three things, namely neglect of the social value of open space, neglecting social costs of using motorized vehicles and failure to calculate the average cost of public infrastructure (Byun and Esparza, 2005). Based on the social value of agricultural or rural land in suburban urban areas as well as the average cost of public infrastructure it is possible to reduce development costs in 
suburban areas. Apart from that, social costs as an effect of externalizing motorized vehicles also contribute to making life in the suburbs relatively cheap. This reason encourages the spread of population to suburban areas (suburban).

\section{CONCLUSION}

Based on the data collected with the help of questionnaires and the results of data analysis, a more indepth study was carried out so that the answers to the problem formulations in this study were obtained. The study was conducted on three aspects, namely: a) The condition of settlements in Denpasar City; b) The tendency of sub-urban communities in choosing the satellite area of Denpasar City as a settlement; and c) the factors considered in choosing a satellite area for Denpasar City.

\section{ACKNOWLEDGMENT}

The authors thank any parties that support this study, also to Udayana University.

\section{REFERENCES}

[1] Anggoti (1993), Metropolis 2000, London : Routhldge.

[2] Budiharjo, Eko \& Sujarto, Djoko (1999), Kota Berkelanjutan : Penerbit Alumni.

[3] Ellisa, Evawani (2009), Realitas dan Tatanan Kota-Kota Urban Di Jepang, Makara Sosial Humaniora Vol. 13, No. 2 : 131-142.

[4] Febriyani, Risna (2014), Pengembangan Wilayah Hinterland di Kecamatan Kadung kandang Sebagai Upaya Peningkatan Pelayanan Publik, Jurnal Administrasi Publik (JAP) Vol. 2, No.3: 440-446.

[5] Ina Helena Agustina (2007), Kajian Tentang Konsep Keberlanjutan pada Beberapa Kota Barudan Permukiman Berskala Besar, Jurnal PWK Unisba.

[6] Kusumaningrum, Dian (2009), Persepsi Wisatawan Nusantara Terhadap Daya Tarik Wisata di Kota Palembang, Yogyakarta: Sekolah Pascasarjana UGM.

[7] Peraturan Pemerintah No. 47 Tahun 1987

[8] Siregar, H. (2006), Perbaikan Struktur dan Pertumbuhan Ekonomi: Mendorong Investasi dan Menciptakan Lapangan Kerja. Jurnal Ekonomi Politik dan Keuangan. Jakarta: INDEF. 